\title{
Pengaruh Pengungkapan Corporate Social Responsibility Pada Nilai Perusahaan Dengan Good Corporate Governance Sebagai Pemoderasi
}

\author{
Ayu Nikita Vira ${ }^{1}$ \\ Made Gede Wirakusuma ${ }^{2}$ \\ ${ }^{1,2}$ Fakultas Ekonomi dan Bisnis Universitas Udayana (Unud), Bali, Indonesia \\ e-mail: ayunikitavira@gmail.com
}

\begin{abstract}
ABSTRAK
Salah satu hal yang dapat mendorong perusahaan mengungkapkan Corporate Social Responsibility dengan baik adalah Good Corporate Governance yang di terapkan pada perusahaan tersebut.Tujuan penelitian ini adalah untuk mengetahui pengaruh pengungkapan CSR pada nilai perusahaan dan peran GCG sebagai pemoderasi yang didukung dengan inkosistensi hasil penelitian terdahulu. Sampel dalam penelitian ini adalah perusahaan pertambangan yang terdaftar di BEI tahun 2013-2017 sejumlah 33 perusahaan. CSR dihitung menggunakan CSRDI GRI G4, Tobin's Q untuk mengukur nilai perusahaan dan proksi GCG diperoleh dengan menentukan skor tertinggi menggunakan metode analisis faktor. Teknik analisis data penelitian ini menggunakan Analisis Regresi Moderasi. Simpulan dari hasil penelitian ini adalah pengungkapan CSR berpengaruh negatif pada nilai perusahaan, serta praktik GCG dapat memperkuat pengaruhpengungkapan CSR pada Nilai Perusahaan pada perusahaan pertambangan yang terdaftar di BEI pada periode 2013-2017.

Kata Kunci: CSR, nilai perusahaan, GCG
\end{abstract}

\begin{abstract}
One thing that can encourage companies to disclose CSR well is GCGwhich applied to the company.The purpose of this study was to determine the effect of CSR disclosure on company value and the role of GCG as moderation which supported by the inconsistency results of previous studies. Sample in this study were mining companies listed on the Indonesia Stock Exchange in 2013-2017 with a total of 33 companies. CSR was calculated using GRI G4 CSRDI, Tobin's $Q$ to measure company value and the GCG proxy was obtained by determining the highest score using the factor analysis method. Data analysis technique of this study uses Moderated Regression Analysis. Conclusions from the results of this study are that CSR disclosure has a negative effect on firm value, and GCG practices can strengthen the effect of CSR disclosure on Corporate Values in mining companies listed on the Stock Exchangeperiod 2013-2017.
\end{abstract}

Keywords: CSR, company value, GCG

\section{PENDAHULUAN}

Derasnya arus globalisasi sangat memberikan dampak pada tatanan ekonomi di era ini. Persaingan antar entitas pun semakin ketat dan perusahaan berlombalomba untuk membenahi perusahaannya agar dapat meningkatkan kualitas dan kinerja untuk mencapai pertumbuhan yang berkelanjutan serta agar perusahaan 
Ayu Nikita Vira dan Made Gede Wirakusuma. Pengaruh...

dapat diakui dengan baik oleh pasar bebas. Namun, tak jarang para pelaku bisnis melupakan pentingnya etika bisnis yang memiliki peran penting bagi suatu perusahaan. Aspek sosial dan lingkungan merupakan aspek yang termasuk di dalam etika bisnis tersebut. Dalam melakukan optimalisasi kinerja dan kualitas demi mencapai tujuan yang diinginkan tidak sedikit pihak pengendali perusahaan yang kurang mementingkan aspek sosial dan lingkungan.

Tujuan utama dari setiap perusahaan menurut theory of the firm adalah untuk mendapatkan keuntungan yang optimal(Saraswathi, 2016), akan tetapi jika bisnisdijalankan dengan melanggar prinsip - prinsip moral dan nilai - nilai etika cenderung akan membahayakan keberlangsungan perusahaan itu sendiri. Perusahaan yang tidak memperhatikan dan tidak menerapkan nilai-nilai moral, cenderung hanya berorientasi untuk memaksimumkan laba yang tergolong dalam tujuan jangka pendek, dan terancam tidak akan mampu untuk bertahan dalam jangka panjang yang bersifat berkelanjutan.

Didorong dengan meningkatnya peran perusahaan antara lain melalui pasar bebas dan globalisasi maka perusahaansemakin luas berinteraksi dan bertanggung jawab sosial dengan masyarakat dan juga pihak lain. Seiring dengan banyaknya perusahaan berkembang, maka kesenjangan sosial dan kerusakan lingkungan di sekitar perusahaan tersebut dapat terjadi(Jessica dan Toly, 2014). Hal tersebut memunculkan kesadaran untuk mengurangi dampak negatif yang dapat terjadi, salah satunya dengan melakukan kegiatan Corporate Social Responsibility (CSR) atau disebut juga dengan tanggung jawab sosial. Kegiatan CSR telah diatur dalam peraturan hukum Negara Indonesia yaitu pada UU Nomor 40 Tahun 2007 yang 
mengatur tentang Perseroan Terbatas yang menjalankan kegiatan usahanya di bidang dan/atau berkaitan dengan sumber daya alam, wajib untuk melaksanakan tanggung jawab sosial dan lingkungan (Anjani dan Astika, 2018).

Terkait dengan perusahaan yang menjalankan kegiatan usahanya berkaitan langsung dengan sumber daya alam, perusahaan sektor pertambangan merupakan perusahaan yang kegiatan pengelolaannya tidak dapat dilepaskan dari eksploitasi sumber daya alam dan berdampak langsung terhadap lingkungan sekitarnya.Sejatinya, sesuai dengan pernyataan yang tercantum dalam UU Nomor 4 Tahun 2009 yang mengatur tentang Pertambangan Mineral dan Batubara yaitu keberadaan aktivitas penambangan umum di Indonesia mempunyai peranan penting dalam memenuhi kebutuhan hidup banyak orang serta memberikan nilai tambah secara nyata bagi perekonomian nasional. Jika dilihat dari kondisi di Indonesia, kegiatan pertambangan seperti mengambil kekayaan alam yang tak terbarukan berupa bahan galian berharga dari lapisan bumi yang berlangsung sejak lama telah menimbulkan dampak lingkungan yang sangat besar.

Terdapat fenomena yang menggambarkan bahwa perusahaan tambang merupakan perusahaan yang sensitif pada dampak pencemaran lingkungan. Fenomena tersebut mengemuka dikarenakan gencarnya isu dari Lembaga Swadaya Masyarakat (LSM) lingkungan yang kerap mengindentikkan pertambangan dengan kerusakan lingkungan. Jaringan Advokasi Tambang (Jatam) di tahun 2012 menyatakan, sekitar 70 persen kerusakan lingkungan Indonesia karena operasi pertambangan. Sekitar 3,97 juta hektar kawasan lindung terancam karena aktivitas pertambangan, termasuk keragaman hayati. Selain itu, 
Ayu Nikita Vira dan Made Gede Wirakusuma. Pengaruh...

Daerah Aliran Sungai (DAS) mengalami peningkatan kerusakan dalam 10 tahun terakhir. Sekitar 4.000 DAS di Indonesia, 108 diantaranya dinyatakan rusak.

Berdasarkan fenomena yang terjadi, perusahaan sektor pertambangan diwajibkan untuk menerapkan program Corporate Social Responsibility berupa program yangmenunjukan kepedulian serta bentuk tanggung jawab perusahaan terhadappihak-pihak yang memiliki hak untuk mendapatkan imbas dari kegiatan CSR tersebut. Corporate Social Responsibility memperluas tanggung jawab perusahaan di luar peran tradisionalnya untuk menyediakan laporan keuangan kepada pemilik modal khususnya pemegang saham. Perluasan tersebut dibuat dengan asumsi bahwa perusahaan mempunyai tanggung jawab yang lebih luas dibanding hanya mencari laba untuk pemegang saham. Mengungkapkan kinerja lingkungan, sosial dan ekonomi yang tercantum dalam laporan tahunan adalah untuk mencerminkan tingkat akuntabilitas, responsibilitas, dan transparansi perusahaan kepada investor dan stakeholder lainnya. (Novita dan Djakman, 2008). Pengungkapan Corporate Social Responsibility diharapkan menjadi hal yang akan meningkatkan kesadaran investor mengenai keberadaan perusahaan.

Isu-isu yang berkaitan dengan reputasi, manajemen risiko, dan keunggulan kompetitif juga nampak menjadi kekuatan yang mendorong perusahaan untuk melakukan pengungkapan Corporate Social Responsibility. Penelitian yang dilakukan oleh Wulandari, et al. (2016) mengungkapkan beberapa alasan mengenai dampak positif dari penerapan CSR diantaranya CSR dapat membangun positioning merk, mendongkrak penjualan, memperluas pangsa pasar, meningkatkan loyalitas karyawan, serta meningkatkan daya tarik 
perusahaan di mata investor. Usaha-usaha pelestarian lingkungan oleh perusahaan akan mendatangkan beberapa keuntungan, diantaranya adalah ketertarikan pemegang saham dan stakeholder terhadap keuntungan yang diperoleh perusahaan akibat pengelolaan lingkungan yang bertanggung jawab (Pfliegeret al., 2005).

Penerapan serta pengungkapan Corporate Social Responsibility akan memberikan sinyal berupa kabar baik bagi publik yang diberikan oleh pihak manajemen bahwa perusahaan memiliki prospek yang baik di masa depan dan memastikan terciptanya sustainability development (Behringer dan Krisztina, 2016). Dengan sinyal tersebut yang membawa kabar baik untuk publik tersebut akan mendatangkan sejumlah manfaat bagi perusahaan itu sendiri, salah satunya yaitu mempertahankan dan mendongkrak reputasi serta citra perusahaan sehingga perusahaan mendapatkan kepercayaan dari banyak pihak serta mengundang ketertarikan para investor untuk menanam saham nya di perusahaan tersebut.

Keputusan investasi menjadi faktor penting dalam fungsi keuangan perusahaan dan faktor penentu nilai perusahaan. Sebagai bentuk tujuan jangka panjang, pihak manajemen sebagai pengelola perusahaan akan selalu berusaha untuk mengoptimalkan nilai perusahaan dengan mengambil keputusan yang dapat menghasilkan harga saham yang maksimal karena hal ini akan berdampak baik dalam memaksimalkan kekayaan pemegang saham.

Beberapa penelitian tentang bagaimana pengaruh pengungkapan Corporate Social Responsibility terhadap nilai perusahaan telah dilakukan, namun terdapat ketidakkonsistenan hasil yang diperoleh dari penelitian yang berbeda. Penelitian 
Ayu Nikita Vira dan Made Gede Wirakusuma. Pengaruh...

yang dilakukan oleh Ramadhani (2012) menemukan hasil yang positif terhadap hubungan pengungkapan Corporate Social Responsibility dengan nilai perusahaan manufaktur yang terdaftar di BEI tahun 2010-2011. Penelitian Latupono dan Andayani (2015) juga menyatakan hal yang sama bahwa pengungkapan Corporate Social Responsibility berpengaruh positif signifikan terhadap nilai perusahaan, serta penerapan Good Corporate Governance (GCG) dengan proksi kepemilikan manajerial mampu memperkuat hubungan antara CSR dan nilai perusahaan.

Berbeda dengan penelitian yang dilakukan oleh Putri, et al. (2016) yang menyatakan pengungkapan Corporate Social Responsibility tidak mempengaruhi nilai perusahaan, namun nilai perusahaan akan dipengaruhi oleh pengungkapan CSR apabila dimoderasi oleh ukuran perusahaan dan jumlah dewan komisaris yang tidak terlalu banyak, penelitian tersebut bertolak belakang dengan pernyataan Collier dan Gregory (1999) bahwa semakin banyak jumlah anggota dewan komisaris, maka akan semakin mudah untuk mengendalikan CEO dan monitoring yang dilakukan akan semakin efektif karena apabila hal tersebut dikaitkan dengan pengungkapan Corporate Social Responsibility, tekanan terhadap manajemen juga akan semakin besar untuk mengungkapkannya.

Hasil penelitian lain yang memiliki hasil negatifyaitu penelitian yang dilakukan oleh Fauziah (2016) yang mengambil sampel perusahaan indeks LQ45 periode 2009-2013 menyimpulkan pengungkapan CSR memberikan pengaruh yang negatif terhadap kinerja finansial dan kinerja saham perusahaan, dalam artian seorang investor dalam membeli saham di perusahaan yang masuk dalam 
indeks LQ45 tidak memprioritaskan aspek CSR dalam pengambilan keputusan investasinya. Penelitian yang dilakukan oleh Fiori, et al. (2007) mengenai CSR yang berkaitan dengan reaksi investor dan memproksi kinerja perusahaan menggunakan stockprice memperoleh hasil CSR tidak signifikan mempengaruhi stock price.

Adanya beberapa hasil penelitian yang berbeda di sejumlah penelitian, maka peneliti tertarik untuk melakukan penelitian dengan judul "Pengaruh Pengungkapan Corporate Social Responsibility pada Nilai Perusahaan dengan Good Corporate Governance Sebagai Pemoderasi” dengan menggunakan teknik analisis yang berbeda dari penelitian sebelumnya yang mengangkat topik serupa dengan penelitian ini. Variabel Good Corporate Governance dipilih sebagai variabel pemoderasi karena GCG merupakan tata kelola perusahaan yang menjelaskan hubungan antara berbagai partisipan dalam perusahaan yang menentukan arah kinerja perusahaan. Pelaksanaan GCG sangat diperlukan untuk memenuhi kepercayaan masyarakat dan berbagai pihak sebagai syarat mutlak bagi perusahaan untuk berkembang dengan baik dan sehat yang tujuan akhirnya untuk mewujudkan shareholder value.

Konsep Good Corporate Governance pada intinya menghendaki adanya transparansi yang lebih baik bagi semua pengguna laporan keuangan yang bila berhasil diterapkan dengan baik secara otomatis akan meningkatkan kinerja perusahaan (Anggreningsih dan Wirasedana, 2017). Dapat dikatakan jika sebuah perusahaan telah menerapkan Good Corporate Governance pada perusahaannya maka berpengaruh dengan tranparansi pengungkapan Corporate Social 
Ayu Nikita Vira dan Made Gede Wirakusuma. Pengaruh...

Responsibility yang dilaporkan pada laporan tahunan adalah sesuai dengan apa yang terjadi di lapangan.

Diantara empat proksi Good Corporate Governance yaitu Kepemilikan Institusional, Kepemilikan Manajerial, Dewan Komisaris Independen, dan Komite Audityang akan digunakan sebagai variabel pemoderasi di penelitian ini adalah proksi yang memiliki skor tertinggi dalam kemampuan menjelaskan hubungan atau korelasi dengan pengungkapan Corporate Social Responsibility dan Nilai Perusahaan. Proksi terbaik ini ditentukan terlebih dahulu dengan menggunakan teknik analisis faktor.

Teknik penentuan proksi pada GCG menjadi hal yang membuat penelitian ini berbeda dengan penelitian sebelumnya yang memliki topik serupa, karena penelitian sebelumnya yang menggunakan variabel Good Corporate Governance mayoritas menggunakan penilaian Corporate Governance Perception Index (CGPI). Penelitian ini mengambil sampel perusahaan pertambangan yang terdaftar di Bursa Efek Indonesia periode tahun 2013-2017 dengan alasan perusahaan sektor pertambangan merupakan salah satu sektor perusahaan yang kegiatan operasional nya langsung berhubungan dengan memanfaatkan sumber daya alam, maka pengungkapan taggung jawab sosial menjadi aspek penting dalam keberlangsungan perusahaan tersebut.

Corporate Social Responsibility atau tanggung jawab sosial perusahaan dapat memberikan kontribusi terhadap kinerja keuangan. Hal ini dikarenakan dalam pengambilan keputusan, perusahaan harus mempertimbangkan berbagai masalah sosial dan lingkungan jika perusahaan ingin memaksimumkan hasil 
keuangan jangka panjang yang nantinya dapat meningkatkan nilai perusahaan. Gunawan dan Utami (2008) menyimpulkan bahwa Corporate Social Responsibility berpengaruh positif padanilai perusahaan, artinya semakin banyak perusahaan mengungkapkan item pengungkapan sosialnya dan semakin baik kualitas pengungkapannya, maka akan semakin tinggi nilai perusahaannya.Hasil pengujian yang dilakukan Rizaldi (2015) menunjukkan hasil yang sama bahwa pengungkapan CSR berpengaruh pada nilai perusahaan. Hal ini sesuai dengan teori stakeholder bahwa perusahaan bukanlah entitas yang hanya beroperasi untuk kepentingan sendiri namun harus memberikan manfaat bagi stakeholder-nya. Apabila perusahaan dapat memaksimalkan manfaat yang diterima stakeholder maka akan timbul kepuasan bagi stakeholder yang akan meningkatkan nilai perusahaan. Berdasarkan uraian hasil kajian empiris tersebut maka hipotesis penelitian ini sebagai berikut:

$\mathrm{H}_{1}$ : Corporate Social Responsibility berpengaruh positif pada nilai perusahaan.

Implementasi CSR merupakan salah satu wujud pelaksanaan prinsip GCG. Perusahaan yang telah melaksanakan Good Corporate Governance dengan sesuai peraturan yang telah diatur sudah seharusnya melaksanakan aktivitas CSR sebagai wujud kepedulian perusahaan pada lingkungan sosial serta mengungkapkannya pada laporan tahunan. Pada penelitian yang dilakukan oleh Guidry dan Patten (2010) menyatakan bahwa perusahaan dengan tingkat kualitas pengungkapan sustainability report yang tinggi memiliki reaksi pasar yang lebih positif dibandingkan kualitas pengungkapan yang rendah. Nilai reputasi saham akan meningkat jika dipengaruhi oleh pengungkapan sustainability report yang 
Ayu Nikita Vira dan Made Gede Wirakusuma. Pengaruh...

meliputi pengungkapan tanggung jawab sosial dan profil tata kelola perusahaan yang baik.

Good Corporate Governance menyangkut tanggung jawab perusahaan kepada pihak-pihak lain yang berkepentingan terutama atas kegiatan ekonomi dan segala dampaknya, sedangkan CSR adalah kegiatan yang diselenggarakan perusahaan sebagai wujud tanggung jawab perusahaan terhadap keberlangsungan masyarakat dan lingkungan sekitar di luar kegiatan utama perusahaan. Kedua kegiatan tersebut sama-sama bertujuan untuk mengoptimalkan nilai perusahaan bagi pemegang saham namun tetap memperhatikan pemangku kepentingan lainnya.

Penelitian yang dilakukan oleh Rustiarini (2010) memperoleh hasil Good Corporate Governance berpengaruh pada hubungan pengungkapan CSR dengan nilai perusahaan. Penerapan Good Corporate Governance mendorong perusahaan melaksanakan aktivitas CSR sehingga dapat meningkatkan reputasi perusahaan.

Sistem kendali perusahaan yang baik akan dapat mengindikasikan meningkatnya kinerja keuangan yang baik, kinerja keuangan yang baik akan menjadi suatu umpan yang dapat menarik perhatian para investor untuk menanamkan sahamnya pada perusahaan, semakin banyak investor yang tertarik untuk membeli saham perusahaan makaharga saham perusahaan akan otomatis naik dan begitu dengan nilai perusahaan yang otomatis menigkat. Sistem kendali yang baik tersebut berhubungan erat dengan keempat mekanisme Good Corporate Governance. Berdasarkan uraian tersebut maka hipotesis yang diajukan adalah berikut: 
$\mathrm{H}_{2}$ : Good Corporate Governancememperkuat pengaruhpengungkapan Corporate Social ResponsibilitypadaNilai Perusahaan.

\section{METODE PENELITIAN}

Penelitian ini dilakukan pada perusahaan sektor pertambangan yang terdaftar di Bursa Efek Indonesia (BEI) pada tahun 2013 sampai 2017. Data diperoleh dengan mengakses dan mengunduh data laporan keuangan dari situs resmi Bursa Efek Indonesia (BEI) dan situs resmi perusahaan. Obyek penelitian ini adalah nilai perusahaan yang dipengaruhi oleh pengungkapan Corporate Social Responsibility dan Good Corporate Governance pada perusahaan pertambangan yang terdaftar di BEI pada tahun 2013 hingga 2017.

Untuk mengetahui nilai perusahaan dalam penelitian ini menggunakan rasio Tobin's Q Perhitungan Tobin's Q (Murnita dan Putra, 2018) diformulasikan sebagai berikut :

$$
\mathrm{Q}=\frac{\mathrm{MVS}+\mathrm{D}}{\mathrm{TA}} \times 100 \%
$$

Keterangan :

$$
\begin{array}{ll}
\mathrm{Q} & =\text { Firm value } \\
\mathrm{MVS} & =\text { Market value of all outstanding shares } \\
\mathrm{D} & =\text { Debt } \\
\mathrm{TA} & =\text { Total Firm's Assets }
\end{array}
$$

Kebijakan pengungkapan CSR diukur dalam jumlah pengungkapan CSR dengan menggunakan proksi Corporate Social Responsibility Index (CSRDI) berdasarkan Global Reporting Inititative Generation 4 (GRI G4) dengan opsi sesuai inti yaitu sebanyak 91 indikator pengungkapan standar khusus.Formulasi perhitungan CSRDI adalah sebagai berikut : 
$\operatorname{CSRDI}=\frac{\sum \mathrm{X} i}{\mathrm{n}} \times 100 \%$

Keterangan :

CSRDI $=$ Corporate Social Responsibility Disclosure Index $(0 \leq$ $\mathrm{CSRDI} \leq 1)$.

$\sum \mathrm{X}_{\mathrm{i}} \quad=$ Jumlah item yang diungkapkan, skor 1 jika diungkapkan, skor 0 jika tidak diungkapkan

$\mathrm{n} \quad=$ Jumlah maksimal item pengungkapan CSRDI pada perusahaan (91 item)

Proksi terbaik didapatkandengan caraanalisis faktorkeempatunsur GCG.

Berikut adalah formulasi perhitungan proporsi dewan komisaris independen:

$$
\text { DKI }=\frac{\text { Jumlah Dewan Komisaris Independen }}{\text { Jumlah Total Dewan Komisaris }} \times 100 \%
$$

Formulasi untuk perhitungan kepemilikan institutional untuk sebuah perusahaan adalah sebagai berikut :

$$
I N S T=\frac{\text { Jumlah Saham Pihak Institusi }}{\text { Total Saham yang Beredar }} \times 100 \%
$$

Pada proksi kepemilikan manajerial akan dihitung presentase jumlah saham yang dimiliki oleh pihak manajerial dengan formulasi sebagai berikut:

$$
K P M J=\frac{\text { Jumlah saham yang dimiliki pihak manajemen }}{\text { Total saham perusahaan yang beredar }} \times 100 \%
$$

Haryani dan Wiratmaja (2014) penelitian ini menggunakan proksi komite audit yang diukur dengan menghitung presentase dari perbandingan jumlah komite audit dengan jumlah total dewan komisaris yang ada dalam perusahaan yang diteliti. Perhitungannya dapat di formulasikan sebagai berikut :

$$
K A=\frac{\text { Jumlah Anggota Komite Audit }}{\text { Jumlah Total Dewan Komisaris }} \times 100 \%
$$

Populasi dalam penelitian ini adalah seluruh perusahaan di sektor pertambangan yang terdaftar di Bursa Efek Indonesia (BEI) periode tahun 2013 hingga 2017serta yang mempublikasikan laporan tahunan nya pada periode 2013 
hingga 2017, serta mengungkapkan laporan kegiatan Corporate Social Responsibility yang telah dilaksanakan. Pada penelitian ini sampel yang digunakan adalah perusahaan pertambangan yang terdaftar di Bursa Efek Indonesia (BEI) periode tahun 2013 hingga 2017 yang dipilih melalui teknik purposive sampling dengan kriteria yang telah ditentukan.

Teknik analisis data yang digunakan dalam penelitian ini adalah MRA. Moderated Regression Analysis dalam persamaan regresinya mengandung unsur interaksi dengan formulasi persamaan sebagai berikut :

$Y=\alpha+\beta_{1} X+\beta_{2} M+\beta_{3} X M+\varepsilon$

Keterangan :

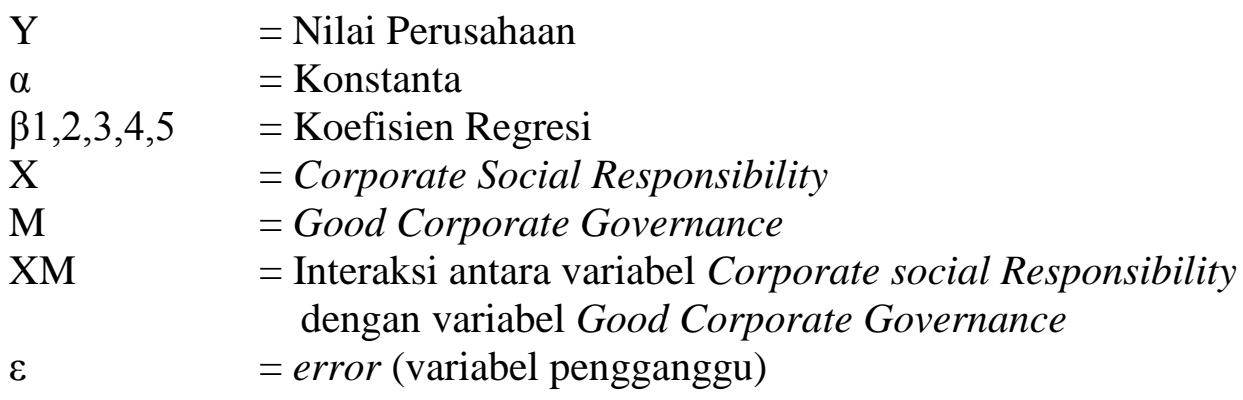

\section{HASIL DAN PEMBAHASAN}

Hasil analisis faktor untuk variabel Good Corporate Governance dapat dilihat pada Tabel 1.

Tabel 1.

Hasil Analisis Faktor

\begin{tabular}{cccc}
\hline Component & Total & \% of Variance & Cumulative \% \\
\hline Dewan Komisaris Independen & 1,303 & 32,586 & 32,586 \\
Kepemilikan Institusional & 1,167 & 29,166 & 61,752 \\
Kepemilikan Manajerial & 0,834 & 20,851 & 82,603 \\
Komite Audit & 0,696 & 17,397 & 100 \\
\hline
\end{tabular}

Sumber: Data diolah, 2018 
Ayu Nikita Vira dan Made Gede Wirakusuma. Pengaruh...

Berdasarkan Tabel 1 Hasil Analisis Faktor diketahui bahwa dua proksi dari GCG memiliki eigenvalue lebih dari 1, varian faktor 1 yaitu dewan komisaris independen dapat menjelaskan 32,586 persen dari variabel Good Corporate Governance sedangkan faktor 2 yaitu kepemilikan institusional dapat menjelaskan 29,166 persen.

Tabel 2.

Hasil Analisis Faktor

\begin{tabular}{ccccc}
\hline Anti-image Correlation & DKI & KI & KM & KA \\
\hline $\begin{array}{c}\text { Dewan Komisaris Independen } \\
\text { Kepemilikan Institusional } \\
\text { Kepemilikan Manajerial } \\
\text { Komite Audit }\end{array}$ & 0,551 & & & \\
\hline Sumber: Data diolah, 2018 & & 0,458 & 0,475 & \\
\end{tabular}

Faktor dapat dikatakan valid apabila faktor tersebut memiliki Measure of Sampling Adequacy (MSA) sama dengan atau lebih dari 0,50. Berdasarkan hasil uji analisis faktor yang tercantum pada Tabel 2 hanya proksi dewan komisaris independen yang memperoleh nilai MSA melampaui angka 0,50 yaitu sebesar 0,551. Maka dapat dikatakan bahwa salah satu dari proksi Good Corporate Governance layak untuk dijadikan variabel pemoderasi pada penelitian. Proksi tersebut adalah Dewan Komisaris Independen yang memperoleh eigenvalue dan nilai MSA tertinggi serta valid memenuhi syarat ketentuan.

Uji Normalitas dilakukan dengan menggunakan Uji Kolmogorov-Smirnov. Hasil Uji Normalitas untuk 165 data yang memenuhi kriteria sampel disajikan pada Tabel 3. 
Tabel 3.

Hasil Uji Normalitas

\begin{tabular}{lc}
\hline & Unstandardized Residual \\
\hline $\mathrm{N}$ & 165 \\
Kologorov-Smirnov & 0,208 \\
Asymp. Sig. (2-tailed) & 0,000 \\
\hline
\end{tabular}

Sumber: Data diolah, 2018

Data dapat dikatakan berdistribusi normal apabila koefisien Asymp. Sig. (2tailed) lebih besar dari 0,05. Berdasarkan Tabel 3 yang menunjukkan hasil dari Uji Normalitas pada 165 data yang memenuhi kriteria diketahui bahwa koefisien Asymp. Sig (2-tailed) adalah sebesar 0,000 yang berarti tidak mencapai kriteria untuk dapat dikatakan data yang normal.

Berdasarkan Tabel 1diketahui bahwa terdapat data outlier sejumlah 28 observasian dari total 165 total jumlah observasian yang telah ditetapkan. Data tersebut di eliminasi karena memiliki nilai yang ekstrim, sehingga menyebabkan data yang diolah tidak berdistribusi normal maka data tersebut harus dikeluarkan dari total data observasi. Setelah dilakukan outlier data tersisa sejumlah 137 total data yang lulus Uji Normalitas dan dapat digunakan untuk Uji Analisis Data.

Statistik deskriptif menyajikan jumlah sampel, nilai maksimum, nilai minimum, nilai rata-rata, serta standar deviasi untuk memberikan informasi mengenai karakteristik variabel-variabel pada penelitian ini. Hasil statistik deskriptif penelitian ini dapat dilihat pada Tabel 4 berikut.

Tabel 4.

Hasil Uji Statistik Deskriptif

\begin{tabular}{cccccc}
\hline & N & Minimum & Maksimum & Mean & Std. Deviasi \\
\hline Nilai Perusahaan & 137 & 0,271 & 1,880 & 0,912 & 0,349 \\
CSR & 137 & 0,065 & 0,901 & 0,398 & 0,207 \\
GCG (Dewan Komisaris & 137 & 0,250 & 0,750 & 0,418 & 0,106 \\
Independen & & & & & \\
Valid N (listwise) & 137 & & & & \\
\hline
\end{tabular}

Sumber: Data diolah, 2018 
Ayu Nikita Vira dan Made Gede Wirakusuma. Pengaruh...

Nilai Perusahaan (Y) dalam penelitian ini dapat didefinisikan sebagai nilai pasar, karena semakin tinggi harga saham, maka dapat diasumsikan semakin tinggi juga tingkat kemakmuran pemegang saham. Untuk menghitung nilai perusahaan digunakan rasio Tobin's Q. Perusahaan pertambangan yang dijadikan sampel penelitian ini memiliki rasio Tobin's Q dengan nilai minimum sebesar 0,271dan nilai maksimum sebesar1,880. Rata-rata rasio Tobin's Q secara keseluruhan yaitu sebesar 0,912 yang berarti bahwa perusahaan pertambangan rata-rata memiliki rasio Tobin's Q menunjukkan nominal dibawah angka 1 mengartikan bahwa masih banyak perusahaan pertambangan yang nilai sahamnya lebih rendah dari harga wajar saham tersebut (undervalued). Standar deviasi rasio Tobin's Q adalah sebesar 0,349.

Corporate Social Responsibility (X) atau tanggung jawab sosial merupakan suatu wujud kepedulian perusahaan terhadap lingkungan dan masyarakat di sekitar tempat perusahaan beroperasi. Nilai minimum CSR pada penelitian ini yaitu sebesar 0,065 yang dapat dikatakan cukup jauh dari nilai ratarata CSR dari keseluruhan sampel pada penelitian ini yaitu sebesar 0,418 yang mengartikan bahwa perusahaan yang memiliki nilai CSR minimum tersebut jumlah skor indikator CSR yang diungkapkan terbilang sangat rendah, sebaliknya nilai maksimum yaitu sebesar 0,901 mengartikan perusahaan yang memiliki nilai CSR maksimum, jumlah skor indikator CSR yang diungkapkan terbilang cukup banyak. Nilai standar deviasi untuk CSR adalah sebesar 0,2073.

Good Corporate Governance (M) yang pada penelitian ini diproksikan dengan dewan komisaris independen berdasarkan hasil dari analisis faktor yang 
telah dilakukan sebelumnya menunjukkan nilai minimum sebesar 0,25 dan nilai maksimum sebesar 0,75 . Nilai minimum tersebut menunjukkan jumlah presentase paling kecil dari perbandingan jumlah dewan komisaris independen dengan total jumlah dewan komisaris yang ada di perusahaan yang menjadi sampel dalam penelitian ini, begitupun sebaliknya dengan nilai maksimum yang menunjukkan jumlah presentase paling besar. Nilai rata-rata yang ditunjukkan adalah sebesar 0,427 dengan standar deviasi sebesar 0,1066.

Pada penelitian ini MRA dilakukan untuk mengetahui apakah variabel Good Corporate Governance mampu memperkuat atau sebaliknya pengaruhCorporate Social Responsibility terhadap nilai perusahaan di perusahaan pertambangan. Hasil analisis MRA dapat dilihat pada Tabel 5 sebagai berikut.

Tabel 5.

Rekapitulasi Hasil Uji Moderated Regression Analysis

\begin{tabular}{|c|c|c|c|c|c|}
\hline Model & Unstanda & Std. Error & $\begin{array}{c}\text { Standardized } \\
\text { Coefficients } \\
\text { Beta }\end{array}$ & $\mathbf{T}$ & Sig. \\
\hline (Constants) & 1,851 & 0,282 & & 6,555 & 0 \\
\hline CSR & $-1,789$ & 0,609 & $-1,061$ & $-2,935$ & 0,004 \\
\hline GCG (DKI) & $-2,070$ & 0,657 & $-0,632$ & $-3,149$ & 0,002 \\
\hline CSR_DKI & 3,930 & 1,476 & 1,004 & 2,662 & 0,009 \\
\hline Adjusted $\mathrm{R}^{2}$ & & & & & 0,059 \\
\hline $\mathrm{F}_{\text {hitung }}$ & & & & & 3,863 \\
\hline Sig. F & & & & & 0,011 \\
\hline
\end{tabular}

Sumber: Data diolah, 2018

Berdasarkan hasil pengujian Moderated Regression Analysis yang tercantum pada Tabel 5 maka dihasilkan persamaan regresi sebagai berikut. $Y=1,851-1,789 X-2,070 M+3,930 X M$

Berdasarkan hasil uji regresi pada Tabel 5 pada halaman 51, diketahui koefisien regresi dari variabel bebas dan interaksi moderasi. Variabel bebas CSR memiliki koefisien $-1,789$ (bernilai negatif). Berdasarkan hasil tersebut 
Ayu Nikita Vira dan Made Gede Wirakusuma. Pengaruh...

mengartikan bahwa CSR memiliki pengaruh yang negatif pada nilai perusahaan. Jika CSR meningkat satu satuan dengan anggapan variabel lainnya konstan akan berdampak menurunkan nilai perusahaan sejumlah 1,789 satuan.

Variabel moderasi GCG memiliki koefisien -2,070 (bernilai negatif) mengartikan bahwa GCG memberikan pengaruh yang negatif pada nilai perusahaan. Jika GCG meningkat satu satuan dengan anggapan variabel lainnya konstan akan berdampak menurunkan nilai perusahaan sejumlah 2,070 satuan.

Koefisien interaksi dari variabel bebas dan variabel moderasi pada nilai perusahaan (CSR_DKI) adalah sejumlah 3,930 (bernilai positif). Dapat diartikan bahwa jika terjadi peningkatan pengungkapan CSR dengan adanya praktik GCG di sebuah perusahaan sejumlah satu satuan dengan anggapan variabel lainnya konstan, maka akan berdampak meningkatkan nilai perusahaan sejumlah 3,930 satuan.

Pada penelitian ini koefisien determinasi dilihat melalui nilai adjusted $\mathrm{R}^{2}$. Adapun nilai dari adjusted $\mathrm{R}^{2}$ pada penelitian ini telah disajikan pada Tabel 5 di halaman 51. Dapat diketahui bahwa nilai dari adjusted $\mathrm{R}^{2}$ adalah sebesar 0,059 yang berarti bahwa 5,9 persen variasi perubahan nilai perusahaan dapat dijelaskan oleh variabel Corporate Social Responsibility dan Good Corporate Governance serta interaksi antara keduanya. Sisanya adalah sebesar 94,1 persen dipengaruhi oleh variabel lain diluar dari model yang digunakan dalam penelitian ini.

Hasil yang diperoleh dari pengujian kelayakan model dalam penelitian ini telah disajikan pada Tabel 5. Berdasarkan tabel tersebut dapat dilihat bahwa nilai dari Uji F adalah sebesar 3,863 dan nilai Sig. F yakni 0,011 lebih kecil dari nilai $\alpha$ 
$=0,05$. Hal ini menunjukkan bahwa model persamaan regresi yang digunakan dalam penelitian ini layak untuk digunakan sebagai alat analisis untuk menguji pengaruh variabel independen dan variabel moderasi pada variabel dependen.

Berdasarkan Tabel 5 hasil uji analisis regresi moderasi diperoleh nilai signifikansi uji t dari variabel Corporate Social Responsibility (X) sebesar 0,004 yang merupakan lebih kecil dari $\alpha=0,05$. Disertai dengan konstanta variabel CSR yang negatif yaitu sebesar $-1,789$. Hal ini mengindikasikan bahwa pengungkapan Corporate Social Responsibility berpengaruh negatif terhadap nilai perusahaan sehingga hipotesis pertama dalam penelitian ini ditolak.

Berdasarkan Tabel 5 diperoleh nilai signifikansi uji t dari interaksi variabel $\mathrm{X}^{*} \mathrm{M}$ untuk variabel pemoderasi Good Corporate Governance mempengaruhi hubungan antara Corporate Social Responsibility terhadap nilai perusahaan sebesar 0,009 lebih kecil dari $\alpha=0,05$. Disertai dengan nilai konstanta yang positif sebesar 3,930. Hal ini menunjukkan bahwa Good Corporate Governance berpengaruh positif dan dapat memperkuat hubungan antara pengungkapan Corporate Social Responsibility terhadap nilai perusahaan, sehingga hipotesis kedua dalam penelitian ini diterima.

Hipotesis pertama menyatakan bahwa pengungkapan Corporate Social Responsibility berpengaruh negatif pada nilai perusahaan. Tabel 4.8 menunjukkan bahwa variabel CSR memiliki koefisien regresi sebesar -1,789 dengan tingkat signifikansi 0,004 lebih kecil dari 0,05. Hasil tersebut menunjukkan bahwa pengungkapan corporate social responsibility berpengaruh negatif pada nilai perusahaan, sehingga hipotesis pertama ditolak. Hasil penelitian ini memiliki hasil 
Ayu Nikita Vira dan Made Gede Wirakusuma. Pengaruh...

yang bertolak belakang dengan hasil penelitian yang dilakukan oleh Latupono dan Andayani (2015) yang juga menyatakan bahwa pengungkapan Corporate Social Responsibility berpengaruh signifikan terhadap nilai perusahaan.

Penelitian ini menyatakan bahwa pengungkapan CSR dapat mempengaruhi nilai perusahaan secara negatif yang berarti bahwa peningkatan pengungkapan CSR pada perusahaan pertambangan akan mengakibatkan penurunan nilai di perusahaan tersebut. Pernyataan ini diperkuat oleh penelitian yang dilakukan oleh Barnett dan Salomon (2006) yang menyatakan bahwa walaupun CSR dilakukan oleh perusahaan untuk mencari kepercayaan dari para investor dan keuntungan secara finansial bagi perusahaan namun CSR merupakan sesuatu yang sangat membebankan perusahaan, dan biaya-biaya yang dikeluarkan oleh perusahaan dapat memposisikan perusahaan dalam kesulitan keuangan yang dapat merusak nilai perusahaan.

Disisi yang sama dinyatakan oleh Margaretha dan Witedjo (2014) bahwa tindakan CSR yang diterapkan sebagai strategi hanya akan menimbulkan penyimpangan dalam penggunaan dana yang dimiliki oleh perusahaan yang dapat memicu rusaknya kinerja keuangan perusahaan. Hal ini diduga karena dana yang dianggarkan cukup banyak dengan pelaksanaan CSR yang kurang pengawasan, maka menimbulkan ketidakefisienan. Pelaksanaan CSR yang kurang pengawasan menyebabkan adanya penyalahgunaan dana yang digunakan untuk perilaku yang oportunis oleh para pelaksana program CSR tersebut.

Merujuk pernyataan pada penelitian yang dilakukan Sayekti dan Wondabio (2007) investor tidak cukup yakin dengan informasi sukarela seperti 
pengungkapan CSR yang diungkapkan pihak manajemen perusahaan, sehingga investor tidak menggunakan informasi tersebut sebagai dasar untuk pengambilan keputusan. Hipotesis kedua pada penelitian ini menyatakan bahwa GCG dapat memperkuat pengaruh antara pengungkapan CSR pada nilai perusahaan. Berdasarkan hasil Moderated Regression Analysis (MRA), diperoleh nilai koefisien untuk variabel interaksi moderasi diketahui sebesar 3,930 dengan signifikansi sebesar 0,009, karena nilai signifikansi adalah lebih kecil dari 0,05 maka dapat dikatakan variabel GCG mampu memoderasi dengan memperkuat hubungan antara pengungkapan CSR dengan nilai perusahaan. Hasil ini menunjukkan bahwa hipotesis kedua pada penelitian ini diterima.

Perusahaan yang melaksanakan tata kelola perusahaan dengan baik pada umumnya akan mengungkapkan tanggung jawab sosial nya dengan transparan, secara apa adanya sesuai dengan apa yang terjadi di lapangan. Pedoman umum GCG di Indonesia menyatakan bahwa salah satu tujuan pelaksanaan GCG adalah untuk mendorong timbulnya kesadaran dan implementasi CSR dari perusahaan bagi masyarakat dan kelestarian lingkungan di sekitar perusahaan sehingga terpelihara kesinambungan usaha dalam jangka panjang (Retno dan Priantinah, 2012).

Dewan komisaris independen sebagai proksi yang mewakili variabel GCG pada penelitian ini sangat memegang peran yang penting bagi perusahaan dalam menerapkan GCG (Putri et al., 2016). Pengawasan yang dilakukan oleh dewan komisaris independen sangat berpengaruh terhadap bagaimana sebuah perusahaan mengungkapkan tanggung jawab sosial nya, sehingga pelaksanaan dari CSR dapat 
sesuai tujuan dan sasaran serta dana yang dialokasikan sepenuhnya tersalurkan dengan baik sesuai yang telah direncanakan.

Tidak akan ada pihak yang dapat berperilaku oportunis dan menyebabkan penyalahgunaan karena adanya pengawasan yang dilakukan oleh pihak dewan komisaris independen selaku pihak yang tidak memiliki sedikitpun afiliasi atau hubungan dengan perusahaan terkait. Penerapan GCG serta CSR sama-sama bertujuan untuk mengoptimalkan nilai perusahaan bagi pemegang saham namun tetap memperhatikan pemangku kepentingan lainnya (Rustiarini, 2010). Dapat disimpulkan bahwa penerapan GCG yang baik akanberdampak positif terhadap CSR yang dilakukan oleh perusahaan tersebut yang juga berdampak positif signifikan terhadap nilai perusahaan.

Hasil penelitian ini memberikan hasil empiris terkait hasil olah data dan statistik di perusahaan pertambangan yang menunjukan bahwa pengungkapan CSR berpengaruh negatif terhadap nilai perusahaan, namun jika dimoderasi atau diperkuat oleh GCG maka hubungan pengungkapan CSR dan nilai perusahaan dapat berpengaruh positif. Hal ini berarti bahwa pengungkapan CSR saja belum dapat dipastikan memberikan sinyalkepada investor untuk menilai sebuah perusahaan bahwa perusahaan tersebut melaksanakan kewajibannya dengan baik yang berdampak pada nilai perusahaan.

Pengungkapan tanggung jawab sosial yang disertakan dengan pengungkapan praktik Good Corporate Governance secara transparan yang mengungkapkan hal-hal yang memberikan manfaat bagi stakehokdernya dan pihak yang berkepentingan dapat dipastikan bahwa hal tersebut merupakan sinyal 
yang baik bagi para investor atau stakeholder, dapat diartikan juga bahwa penelitian ini mendukung adanya Teori Stakeholder dan Teori Sinyal.

Adanya pengungkapan tata kelola perusahaan yang baik diantaranya dicantumkannya profil dan jumlah dewan komisaris terutama dewan komisaris independen menggambarkan bahwa kegiatan pengawasan dalam perusahaan dapat berjalan dengan baik, dengan hal tersebut konflik keagenan yang tidak diinginkan dapat dicegah sesuai dengan penjelasan Teori Keagenan, para investor atau stakeholder pun tidak akan ragu untuk menentukan pilihan serta meletakkan kepercayaan untuk menanam saham pada perusahaan yang membagikan informasi secara jelas yang dapat memberikan nilai tambah perusahaan. maka penelitian ini dapat meguatkan Teori Legitimasi yang menyatakan apabila perusahaan melakukan sesuatu yang memberikan dampak positif maka akan mendapatkan kepercayaan serta dukungan dari banyak pihak yang bersangkutan.

\section{SIMPULAN}

Penelitian ini bertujuan untuk mengetahui bagaimana pengaruh pengungkapan Corporate Social responsibility pada nilai perusahaan serta untuk mengetahui apakah pengungkapan Good Corporate Governance dapat memperkuat pengaruh CSR terhadap nilai perusahaan pertambangan yang terdaftar di BEI pada tahun 2013 - 2017. Sebanyak 137 pengamatan diperoleh dan berdasarkan hasil analisis dan pembahasan maka dapat disimpulkan bahwa pengungkapan Corporate Social Responsibility berpengaruh negatif terhadap Nilai Perusahaan di perusahaan pertambangan yang terdaftar di BEI periode 2013-2017. Artinya semakin tinggi 
Ayu Nikita Vira dan Made Gede Wirakusuma. Pengaruh...

pengungkapan CSR perusahaan pada pelaporan tahunan, dapat menurunkan nilai perusahaan tersebut. Hal ini tidak sesuai dengan hipotesis penelitian yang pertama. Dana yang berlebihan diinvestasikan dalam bentuk tanggung jawab sosial sangat riskan disalahgunakan dan tidak efisien apabila tidak adanya pengawasan, dengan demikian investor tidak cukup yakin dengan informasi sukarela seperti pengungkapan CSR yang diungkapkan pihak manajemen perusahaan.

Praktik Good Corporate Govenance dapat memperkuat pengaruh pengungkapan CSR terhadap nilai perusahaan di perusahaan pertambangan yang terdaftar di BEI pada periode 2013-2017. Berarti bahwa pengungkapan CSR dapat berpengaruh positif terhadap nilai perusahaan apabila diperkuat dengan dilaksanakannya praktik GCG. Adanya pihak perusahaan yang bertanggung jawab melakukan pengawasan yaitu dewan komisaris, khususnya dewan komisaris independen akan mempengaruhi bagaimana sebuah perusahaan mengungkapkan tanggung jawab sosialnya, sehingga pelaksanaan dari CSR dapat sesuai tujuan dan sasaran serta dana yang dialokasikan sepenuhnya tersalurkan dengan baik sesuai yang telah direncanakan.

Bagi perusahaan, untuk meningkatkan firm value dapat melakukan pelaksanaan CSRsebagai wujud kepedulian pada aspek lingkungan dan sosial dengan memperhatikan keberlangsungan hidup perusahaan dalam jangka panjang dengan membangun citra perusahaan yang baik didukung juga dengan praktik GCGserta diungkapkan secara transparan berdasarkan prinsip-prinsip dari GCG 
agar dapat meningkatkan rasa kepercayaan pihak stakeholder dan para calon investor.

Bagi para investor, dengan adanya penelitian ini dan hasil yang sudah dijabarkan disarankan agar dapat bertindak bijak dalam kegiatan berinvestasi, mempertimbangkan hal-hal yang akan dapat mempengaruhi nilai sebuah perusahaan secara matang sebelum melakukan kegiatan investasi, untuk meminimalisir resiko yang dapat timbul.

Berdasarkan hasil uji koefisien determinasi $\left(\mathrm{R}^{2}\right)$ pada penelitian ini yang terbilang rendah yakni sebesar 5,9 persen yang menunjukkan adanya keterbatasan variabel independen yang digunakan dalam penelitian ini untuk menjelaskan variabel dependen. Dari total 100 persen, variabel independen hanya dapat menjelaskan 5,9 persen dari variabel dependen di penelitian ini, sedangkan sisanya sebesar 94,1 persen dari variabel dependen tidak dapat dijelaskan. Jadi, dapat diasumsikan bahwa terdapat faktor-faktor lain diluar dari model penelitian ini yang dapat mempengaruhi nilai perusahaan. Sehingga, untuk penelitian selanjutnya disarankan untuk dapat menambah atau mempertimbangkan kemungkinan variabel independen lainnya yang dapat mempengaruhi nilai perusahaan.

\section{REFERENSI}

Anggreningsih, K. Y., \& Wirasedana, I. W. P. (2017). Corporate Governance Sebagai Pemoderasi Pengaruh Asimetri Informasi Terhadap Praktik Manajemen Laba. E-Jurnal Akuntansi Universitas Udayana, 19(3), 22622292.

Anjani, N., \& Astika, I. B. P. (2018). Pengaruh Pengungkapan Corporate Social 
Responsibility pada Nilai Perusahaan dengan Likuiditas Perusahaan sebagai Pemoderasi. E-Jurnal Akuntansi Universitas Udayana, 24(2), 899-928.

Barnett, M. L., \& Salomon, R. M. (2006). Beyond Dichotomy: The Curvilinear Relationship Between Social Responsibility And Financial Performance. Strategic Management Journal in Wiley InterScience (Www.Interscience.Wiley.Com), 1101-1122. https://doi.org/10.1002/smj

Behringer, K., \& Krisztina, S. (2016). The Role Of CSR In Achieving Sustainable Development - Theoretical Approach. European Scientific Journal, 12(22), 10-25. https://doi.org/10.19044/esj.2016.v12n22p10

Collier, P., \& Gregory, A. (1999). Audit Committee Activity and Agency Cost. Journal of Accounting and Public Policy, 18, 311-332.

Fauziah, G. (2016). Pengaruh Pengungkapan Corporate Social Responsibility terhadap Nilai Perusahaan pada Indeks Saham LQ 45. Jurnal Manajemen IKM Institut Pertanian Bogor, Vol. 11(1), 1-46.

Fiori, G., di Donato, F., \& Izzo, M. F. (2007). Corporate Social Responsibility and Firms Performance - An Analysis on Italian Listed Companies. SSRN Electronic Journal, 1-14. https://doi.org/10.2139/ssrn.1032851

Guidry, R. P., \& Patten, D. (2010). Market reactions to the first-time issuance of Corporate Sustainability Reports: Evidence that quality matters. Sustainability Accounting, Management and Policy Journal, 1(1), 33-50.

Gunawan, B., \& Utami, S. S. (2008). Peranan Corporate Social Responsibility Dalam Nilai Perusahaan. Jurnal Akuntansi Dan Keuangan Universitas Muhammadiyah Yogyakarta, 7(2), 174-185.

Haryani, J., \& Wiratmaja, I. D. N. (2014). Pengaruh Ukuran Perusahaan , Komite Audit , Penerapan International Financial Reporting Standards Dan Kepemilikan Publik Pada Audit Delay. E-Jurnal Akuntansi Universitas Udayana, 6(1), 63-78.

Jessica, \& Toly, A. A. (2014). Pengaruh Pengungkapan Corporate Social Rerponsibility Terhadap Agresivitas Pajak. Jurnal Akuntansi Bisnis Universitas Kristen Petra, 4(1), 1-9.

Latupono, S. S., \& Andayani. (2015). Pengaruh Corporate Social Responsibility Terhadap Nilai Perusahaan: Good Corporate Governance Variabel Moderating. Jurnal Ilmu Dan Riset Akuntansi STIESIA Surabaya, 4(8), 1-15. https://doi.org/10.1080/17450140600679883

Lestari, S. D., \& Wirawati, N. G. P. (2016). Good Corporate Governance Sebagai 
Pemoderasi Pengaruh Asimetri Informasi Pada Manajemen Laba. E-Jurnal Akuntansi Universitas Udayana, 16(1), 156-182.

Margaretha, F., \& Witedjo, C. G. (2014). CSR, Nilai Perusahaan dan Kinerja Keuangan Perusahaan pada Industri Pertambangan dan Manufaktur di Indonesia. Media Riset Akuntansi, Auditing \& Informasi Universitas Trisakti, 14(1), 89-115.

Murnita, P. E. M., \& Putra, I. M. P. D. (2018). Pengaruh Corporate Social Responsibility terhadap Nilai Perusahaan dengan Profitabilitas dan Leverage sebagai Variabel Pemoderasi. E-Jurnal Akuntansi Universitas Udayana, 23(2), 1470-1494.

Nila, L., \& Suryanawa, I. K. (2018). Pengaruh Profitabilitas dan Ukuran Perusahaan Terhadap Nilai Perusahaan dengan Pengungkapan Corporate Social Responsibility Sebagai Pemoderasi. E-Jurnal Akuntansi Universitas Udayana, 23(3), 2145-2174.

Novita, \& Djakman, C. (2008). Pengaruh Struktur Kepemilikan terhadap Luas nya Pengungkapan Tanggung Jawab Sosial (CSR Disclosure) pada Laporan Tahunan Perusahaan: Studi Empiris pada Perusahaan Publik yang Tercatat di Bursa Efek Indonesia Tahun 2006. Proceeding SNA 11. Pontianak.

Pflieger, J., Fischer, M., Kupfer, T., \& Eyerer, P. (2005). The Contribution of Life Cycle Assessment to Global Sustainability Reporting of Organization. Management of Environmental Journal, 16.

Putra, A. G. T. D., \& Wirakusuma, M. G. (2017). Pengaruh Corporate Social Responbility Disclosure Terhadap Nilai Perusahaan Dengan Kepemilikan Asing Sebagai Variabel Pemoderasi. E-Jurnal Akuntansi Universitas Udayana, 19(3), 1719-1746.

Putri, A. K., Sudarma, M., \& Purnomosidhi, B. (2016). Pengaruh Corporate Social Responsibility terhadap Nilai Perusahaan dengan Ukuran Perusahaan dan Jumlah Dewan Komisaris sebagai Variabel Pemoderasi ( Studi pada Perusahaan Manufaktur yang terdaftar Bursa Efek Indonesia ). Jurnal Aplikasi Manajemen Universitas Brawijaya, 14(2), 344-358.

Ramadhani, L. S. (2012). Pengaruh Corporate Social Responsibility Terhadap Nilai Perusahaan Dengan Prosentase Kepemilikan Manajemen Sebagai Variabel Moderating Pada Perusahaan Manufaktur Yang Terdaftar Di Bei. Diponegoro Journal of Accounting, 8(3), 1-14.

Retno, R. D., \& Priantinah, D. (2012). Pengaruh Good Corporate Governance dan Pengungkapan Corporate Social Responsibility Terhadap Nilai Perusahaan. Jurnal Nominal Ekonomi Universitas Negeri Yogyakarta, I(1), 84-103. 
Rizaldi, A. (2015). Pengaruh Corporate Social Responsibility (CSR) terhadap Nilai Perusahaan dengan Profitabilitas sebagai Variabel Moderating. Artikel Ilmiah Sekolah Tinggi Ilmu Ekonomi Perbanas, 1-15.

Rustiarini, N. I. W. (2010). Pengaruh Corporate Governance Pada Hubungan CSR dan Nilai Perusahaan. Proceeding SNA 13. Purwokerto.

Saraswathi, I. . A. (2016). Pengaruh Risiko Bisnis, Pertumbuhan Perusahaan dan Struktur Modal terhadap Profitabilitas serta Nilai Perusahaan Manufaktur. EJurnal Ekonomi Dan Bisnis Universitas Udayana, 5(6), 1729-1756.

Sayekti, Y., \& Wondabio, L. S. (2007). Pengaruh CSR Disclosure terhadap ERC. Proceeding SNA 10. Makassar.

Utami, A. S. (2011). Pengaruh Kinerja Keuangan Terhadap Nilai Perusahaan Dengan Pengungkapan Corporate Social Responsibility Dan Good Corporate Governance Sebagai Variabel Pemoderasi. Jurnal Akuntansi Universitas Jember, 34(2), 281-293. https://doi.org/10.1080/01402390.2011.569130

Wulandari, A., Ramantha, I. W., \& Wirakusuma, M. G. (2016). Dampak Moderasi Profitabilitas terhadap Pengaruh Corporate Social Responsibility pada Nilai Perusahaan Manufaktur. E-Jurnal Akuntansi Universitas Udayana, 5(7), 1889-1918. 